\section{References}

${ }^{1}$ McConkey B, Davies P, Crockson RA, et al. Effects of gold, dapsone and prednisone on serum C-reactive protein and haptoglobin and the erythrocyte sedimentation rate in rheumatoid arthritis. Ann Rheum Dis $1979 ; 38: 141-4$.

2 Barnetson R StC, Pearson JMH, Rees RJW. Evidence for prevention of borderline leprosy reactions by dapsone. Lancet 1976;ii:1171-2.

${ }^{3}$ Svartz N. The treatment of rheumatic polyarthritis with acid azo compounds. Rheumatism 1948;4:56-60.

${ }^{4}$ Rubinstein A, Das KM, Melamed J, Murphy RA. Comparative analysis of systemic immunological parameters in ulcerative colitis and idiopathic proctitis: effects of sulfasalazine in vivo and in vitro. Clin Exp Immunol $1978 ; 33: 217-24$

${ }^{5}$ Kuzell WC, Gardner GM. Salicylazosulfapyridine (salazopyrin or azopyrin) in rheumatoid arthritis and experimental polyarthritis. Calif Med $1950 ; 73: 476-80$.

6 Sinclair RJG, Duthie JJR. Salazopyrin in the treatment of rheumatoid arthritis. Ann Rheum Dis 1948;8:226-31.

7 McConkey B, Amos RS, Butler EP, Crockson RA, Crockson AP, Walsh L. Salazopyrin in rheumatoid arthritis. Agents Actions 1978;8:438-41.
${ }^{8}$ McConkey B, Crockson RA, Crockson AP. The assessment of rheumatoid arthritis: A study based on measurements of the serum acute-phase reactants. $Q \mathcal{F}$ Med $1972 ; 41: 115-25$.

${ }^{9}$ McConkey B, Crockson RA, Crockson AP, Wilkinson AR. The effects of some anti-inflammatory drugs on the acute-phase proteins in rheumatoid arthritis. $Q \mathcal{F}$ Med 1973;42:785-91.

${ }^{10}$ Schneider RE, Beeley L. Megaloblastic anaemia associated with sulphasalazine treatment. Br Med f 1977;i:1638-9.

11 Schröder H, Campbell DES. Absorption, metabolism and excretion of salicyl-azo-sulfapyridine in man. Clin Pharmacol Ther 1972;13:539-51.

${ }^{12}$ Holm G, Perlman P. The effect of antimetabolites on the cytotoxicity by human lymphocytes. Dausset J, Hamburger J, Mathe G, eds. I: Advance in transplantation. Copenhagen, Munksgaard, 1968:155-61.

${ }^{13}$ West $B$, Lendrum R, Hill MJ, Walker G. Effects of sulphasalazine (salazopyrin) on faecal flora in patients with inflammatory bowel disease. Gut 1974;15:960-5.

${ }^{14}$ Rheumatoid arthritis and the gut. $\operatorname{Br} \operatorname{Med} \mathcal{F} 1979$;i:1104.

\title{
Prolongation of canine pancreas allograft survival with cyclosporin A: preliminary report
}

\section{PAUL MCMASTER, A PROCYSHYN, R Y CALNE, R VALDES, K ROLLES, DAVID J SMITH}

\section{Summary and conclusions}

Studies were conducted on dogs to test the efficacy of cyclosporin $A(C y A)$ in prolonging normoglycaemia and graft survival after whole-organ pancreas allograft transplantation. Five dogs subjected to pancreatectomy alone served as controls.

Withholding immunosuppression after transplantation (five animals) resulted in the same median duration of survival as occurred in the controls (13 days). Azathioprine and steroids (seven animals) produced median durations of normoglycaemia and survival of 9 and 23 days respectively. Animals given CyA $18 \mathrm{mg} / \mathrm{kg} / \mathrm{day}$ (five) and $25 \mathrm{mg} / \mathrm{kg} /$ day (10), however, showed median durations of normoglycaemia of 18 and 55 days $(p<$ 0.05 and $p<0.02)$ respectively and median survival times of 36 and 85 days (NS and $p<0.02$ ).

If CyA proved effective in controlling rejection of pancreas allografts in man it would offer unstable diabetics in renal failure a more hopeful outlook than conventional immunosuppression.

\section{Introduction}

Many children with insulin-dependent diabetes develop complications of their disease, and their life span is greatly reduced. ${ }^{1}$ Renal failure accounts for an increasing number of deaths, ${ }^{2}$ and after three years the survival of diabetics receiving dialysis is less than half that of non-diabetics receiving dialysis. ${ }^{3}$

\footnotetext{
University Department of Surgery, Addenbrooke's Hospital, Cambridge CB2 2QQ

PAUL MCMASTER, CHM, FRCS, consultant surgeon

A PROCYSHYN, MD, research fellow

R Y CALNE, MS, FRCS, FRS, professor of surgery

$R$ VALDES, MD, research fellow

K ROLLES, BSC, FRCS, senior surgical registrar

DAVID J SMITH, chief technician
}

Cadaveric renal transplantation is also less successful in diabetic patients, with an increased morbidity and a reduction in patient and graft survival. ${ }^{*}$

Transplantation of the pancreas has been tried to improve carbohydrate control by producing a more consistent biological release of insulin, but the results of both islet and whole-organ grafting are disappointing. ${ }^{5}$ Rejection is difficult to control, and using steroids may disturb carbohydrate metabolism. Thus to find an alternative to steroids in controlling rejection we have tested the non-steroidal fungal metabolite cyclosporin A (CyA).

\section{Materials and methods}

Unrelated mongrel dogs were studied. As controls we used five animals (group 1) subjected to total pancreatectomy under general anaesthesia, great care being taken to remove all pancreatic tissue. In the other animals (groups 2-5) total pancreatectomy was followed by transplanting a whole-organ pancreas allograft heterotopically in the right iliac fossa, the donor coeliac axis being anastomosed to the external iliac artery, and the donor portal vein end-to-side to the recipient iliac vein. The main donor pancreatic duct was occluded by direct ligation or by ligation and $2 \mathrm{ml}$ latex duct injection.

In group 2 (five animals) immunosuppression was withheld after transplantation; in group 3 (seven animals) transplantation was followed by treatment with azathioprine $3 \mathrm{mg} / \mathrm{kg}$ and prednisolone $1.5 \mathrm{mg} / \mathrm{kg}$ daily; in group 4 (five animals) transplantation was followed by CyA alone $18 \mathrm{mg} / \mathrm{kg} /$ day; and in group 5 (10 animals) transplantation was followed by CyA $25 \mathrm{mg} / \mathrm{kg}$ daily.

Normoglycaemia was recorded only when random non-fasting blood sugar concentrations postoperatively remained less than twice the preoperative fasting value.

\section{Results}

Transplantation without immunosuppression (group 2) did not prolong survival as compared with pancreatectomy alone, and the median duration of normoglycaemia was four days as compared with less than one (table I). Animals given azathioprine and steroids (group 3) showed a median period of normoglycaemia of nine days and a median survival of 23 days ( $p>0.05$; Mann-Whitney twosample non-parametric test). Animals given CyA, however, both at 
TABLE I-Durations of normoglycaemia and survival in the five groups of animals

\begin{tabular}{|c|c|c|c|c|c|}
\hline & Group & $\begin{array}{c}\text { Normoglycaemia } \\
\text { (days) }\end{array}$ & Median & $\underset{\text { (days) }}{\text { Survival }}$ & Median \\
\hline & $\begin{array}{l}\text { Pancreatectomy alone } \\
\text { Pancreas transplantation, no immunosuppressive treatment } \\
\text { Pancreas transplantation + azathioprine and steroids } \\
\text { Pancreas transplantation + CyA } 18 \mathrm{mg} / \mathrm{kg} \\
\text { Pancreas transplantation + CyA } 25 \mathrm{mg} / \mathrm{kg}\end{array}$ & $\begin{array}{l}<1,<1,<1,<1,<1 \\
4,4,4,6,7 \\
1,4,4,9,16,29,74 \\
11,15,18,55,96 \\
17,25,31,35,53,57,60,90,92,97\end{array}$ & $\begin{array}{c}<1 \\
4 \\
9 \\
18^{*} \\
55^{* *}\end{array}$ & $\begin{array}{l}7,8,13,22,24 \\
8,13,13,22,25 \\
8,10,22,23,23,29,77 \\
11,25,36,57,134 \\
23,35,43,44,81,89,92,92,94,129\end{array}$ & $\begin{array}{l}13 \\
13 \\
23 \\
36 \\
85^{* *}\end{array}$ \\
\hline
\end{tabular}

Transplant groups (3-5) $v$ untreated pancreas allograft group (2): ${ }^{*} \mathrm{p}<0.05 ;{ }^{*} \mathrm{p}<0.02$ (Mann-Whitney two-sample non-parametric test).

TABLE II-Results of glucose tolerance tests before and after transplantation in five group 5 animals remaining normoglycaemic for over 50 days postoperatively. Postoperative values represent the last obtained before the animals became diabetic. Figures are means $\pm S D$ (mmol/l)

\begin{tabular}{|c|c|c|c|c|c|c|c|}
\hline & \multicolumn{7}{|c|}{ Time after glucose loading (min) } \\
\hline & 0 & 10 & 20 & 30 & 60 & 90 & 120 \\
\hline $\begin{array}{l}\text { Before } \\
\text { After }\end{array}$ & $\begin{array}{l}4.51 .1 \\
4.8 \pm 0.9\end{array}$ & $\begin{array}{l}7 \cdot 8 \pm 1 \cdot 7 \\
8 \cdot 3 \pm 1 \cdot 5\end{array}$ & $\begin{array}{l}10 \cdot 1 \pm 1 \cdot 6 \\
12 \cdot 2 \pm 1 \cdot 9\end{array}$ & $\begin{array}{l}12.5 \pm 0.7 \\
13.4 \pm 1.7\end{array}$ & $\begin{array}{r}9.3 \pm 1.4 \\
10.5 \pm 1.7\end{array}$ & $\begin{array}{l}5 \cdot 3 \pm 2 \cdot 0 \\
6 \cdot 1 \pm 1 \cdot 6\end{array}$ & $\begin{array}{l}4 \cdot 9 \pm 1 \cdot 6 \\
5 \cdot 0 \pm 1 \cdot 2\end{array}$ \\
\hline
\end{tabular}

Conversion: SI to traditional units-Glucose: $1 \mathrm{mmol} / \mathrm{l} \approx 18 \mathrm{mg} / 100 \mathrm{ml}$.

18 and $25 \mathrm{mg} / \mathrm{kg}$, showed a statistically significant prolongation of normoglycaemia $(p<0.05$ and $p<0.02$ respectively) as compared with that in group 2. Combining all the CyA-treated dogs in groups 4 and 5 showed a significant increase in the period of normoglycaemia compared with that in animals given azathioprine and steroids $(\mathrm{p}<0 \cdot 05)$. Animals given $25 \mathrm{mg} \mathrm{CyA} / \mathrm{kg}$ survived significantly longer than the untreated animals (group $2 ; \mathrm{p}<0.02$ ), and all the CyAtreated dogs in groups 4 and 5 taken together showed significant prolongation of survival compared with that in group $3(p<0.02)$.

Table II summarises the results of intravenous glucose tolerance tests $(0.5 \mathrm{~g}$ glucose $/ \mathrm{kg})$ before and after operation in five of the group 5 animals remaining normoglycaemic for over 50 days. Post-transplant values represent the last available before the animals became diabetic.

\section{Comment}

Undoubtedly azathioprine and prednisolone significantly prolong pancreas graft survival in animals and man, though in mongrel dogs rejection is often rapid and severe. In our study, with each dog's preoperative blood sugar concentration acting as his own control and rigid criteria being used to define normoglycaemia after pancreas transplantation, prolongation of normoglycaemia at the dosage of conventional immunosuppression was not achieved.

CyA may impressively increase survival of animal organ allografts ${ }^{6-8}$ and though its mechanism of action is far from clear, our preliminary studies in man suggested that it may also be effective on its own as an immunosuppressive agent in renal transplantation. If it is also effective in controlling rejection of pancreas allogfrats in man it may offer the unstable diabetic in renal failure a more hopeful outlook with pancreas transplantation than present management with standard immunosuppression.

\section{References}

1 Editorial. Diabetic complication in childhood. Br Med $\mathcal{F} 1978$;i:941

${ }^{2}$ Marks HH. Longevity and mortality of diabetics. Am $\mathcal{F}$ Public Health 1965; $55: 416-23$.

${ }^{3}$ Shapiro FL, Leonard A, Comty CM. Mortality, morbidity and rehabilitation results in regularly dialysed patients with diabetes mellitus. Kidney Int $1974 ; 6$, suppl $1: S-8$.

4 Jervell J, Dahl BO, Flatmark A, et al. Renal transplantation in insulindependent diabetics, Lancet 1978;ii:915-7.

5 Najarian JS, Sutherland DER, Matas AJ, Goetz FC. Human islet autotransplantation following pancreatectomy. Transplant Proc 1979;XI, No $1: 336-40$.

6 Borel JF, Feurer C, Gubler HU, Stahelin H. Biological effects of cyclosporin A: a new antilymphocytic agent. Agents Actions 1976;6:468-75.

${ }^{7}$ Kostakis AJ, White DJG, Calne RY. Prolongation of the rat heart allograft survival by cyclosporin A. IRCS Med Sci 1977;5:280.

${ }^{8}$ Calne RY, White DJG, Pentlow BD, et al. Cyclosporin A: preliminary observations in dogs with pancreatic duodenal allografts and patients with cadaveric renal transplants. Transplant Proc 1979;XI, No 1: $860-4$.

(Accepted 27 November 1979)
ONE HUNDRED YEARS AGO The condition of Captain Webb, during his extraordinary feat of remaining sixty hours in water in the tank at the Westminster Royal Aquarium, and after its conclusion, has been carefully observed by Mr F J Gant, who has presented us with some notes taken by him. The water in the tank was a solution of bay-salt, of specific gravity 1027, and having a temperature varying from $75^{\circ}$ to $87^{\circ} \mathrm{Fahr}$, the mean being $81^{\circ}$. Captain Webb swam and floated for 38 hours and 52 minutes, when he left the tank for 21 minutes; after which he remained in the water till the completion of the 60 hours. His food consisted chiefly of minced steak and fat in equal proportion, with eggs; this was made into balls, which he took from a board. For drink, he had chiefly beef-tea and coffee, strong green tea occasionally, and one glass of Burton ale, which, he thought, did not agree with him. Urine was passed five or six times in the water; and he had one solid alvine evacuation, during his absence from the tank. He did not sleep; but dozed occasionally while floating on his back. On leaving the bath on Wednesday night, he appeared fresh and well. Mr Gant made the following notes of his condition at this time. Temperature in mouth, $97.2^{\circ} \mathrm{Fahr}$; surface of body felt quite warm; pulse 64, rather weak and irregular, small and compressible; respiration normal; tongue clean and moist; no nausea, salt-water not having been swallowed during the swim; mental faculties perfect; pupils not dilated; no conjunctival congestion. Drowsiness soon supervened, and he slept for half-an-hour. Then, after a short interval, again fell into a placid sleep for two hours. On standing up, he felt giddy and faint. He now had brandy and soda-water, turtle soup, and a mutton cutlet. The urine passed immediately after emersion was rather pale and opalescent, slightly acid, of specific gravity 1018 (when cold), and contained half an ounce of mucus in six ounces. His cheeks were pink-red, slightly chapped. The skin was generally sound and of usual colour. There was a red mark on the back of the neck from friction of his jersey. There were erythematous patches on the lower portion of the thighs, and red marks in the flexures of the knees. Fourteen hours after leaving the water, he was removed to the Westminster Palace Hotel, after two hours' sleep at the Aquarium, and having taken supper and smoked a cigar. He then went to bed, where he slept soundly about six hours. The temperature on Thursday morning was $97.8 \mathrm{Fahr}$; pulse 72 . The erythema of the thighs had nearly disappeared. In the flexure of the right knee were a few small sloughy spots, from friction. The skin was generally quite natural; there was no desquamation of the cuticle. He felt quite well. (British Medical fournal, 1880.) 